\title{
Rusmiddelbruk i Norge
}

\author{
Ingeborg Rossow \\ Norsk institutt for forskning om oppvekst, velferd og aldring (NOVA), Munthes gt. 29, 0260 Oslo
}

\section{INNLEDNING}

Jeg vil i denne oversiktsartikkelen gi en kort beskrivelse av hva vi vet om bruk og misbruk ${ }^{1}$ av ulike rusmidler i Norge, i hovedsak basert på nyere epidemiologiske studier og tilgjengelig statistikk. Vår kunnskap om det 'usynlige misbruket' (av avhengighetsskapende legemidler) er pinlig beskjeden, og det er en særlig viktig utfordring for rusmiddelforskningsfeltet og tilgrensende miljøer å framskaffe bedre kunnskap om bruk og misbruk av avhengighetsskapende legemidler. Når det gjelder bruk og misbruk av alkohol og narkotika, er omfanget og bredden i kunnskapstilfanget vesentlig bedre. Det er likevel forskningsmessige utfordringer også på disse temaene, og dette kommer jeg litt inn på avslutningsvis.

\section{ALKOHOL \\ Totalkonsumet}

Det rusmidlet vi har desidert lengst og mest erfaring med her i landet, er alkohol. Rundt $90 \%$ av den voksne befolkningen har drukket alkohol i løpet av det siste året. Et vanlig brukt mål på hvor mye vi drikker, er totalkonsumet $\mathrm{i}$ befolkningen, oftest angitt som gjennomsnittlig årskonsum i liter ren alkohol per innbygger over 15 år. I år 2000 var dette 5,6 liter ren alkohol per innbygger over 15 år. Dette tallet er basert på den registrerte omsetningen av alkohol (på vinmonopolet, $\mathrm{i}$ forretninger og på skjenkesteder). I tillegg til dette kommer det uregistrerte konsumet (i hovedsak fra lovlig turistimport, innsmuglet alkohol, samt hjemmebrent sprit og vinlegging).

Tabell 1 gir et bilde av omfanget og fordelingen av registrert og uregistrert alkoholkonsum. Som vi ser, gir de registrerte salgstallene et bilde av nordmenn som et øldrikkende folk. Men, også når vi tar hensyn til det uregistrerte konsumet, som domineres av vin og brennevin, utgjør ølkonsumet en større andel av det totale konsumet enn vin og brennevin. Det er også verd å merke seg at det uregistrerte konsumet utgjør omkring en firedel av det totale alkoholkonsumet (Horverak et al., 2001) $)^{2}$.

Drikker vi mer nå enn før? Svaret avhenger helt av hvilken tidsperiode vi sammenlikner med. Tall for det registrerte alkoholkonsumet går helt tilbake til 1851, og disse viser at konsumet har variert voldsomt i løpet av de halvannet hundre årene som vi har tall for. Som vi ser av Figur 1, har vi et konsum nå som i hovedsak ligger høyere enn hva vi har hatt $\mathrm{i}$ tidligere perioder, men det har også vært perioder i siste halvdel av 1800- tallet med et enda høyere konsum. Rundt 1920 var konsumet lavt som følge av det partielle alkoholforbudet ('forbudstiden'), og det var også lavt under 2. verdenskrig. Ser vi på utviklingen på 1990-tallet, ser vi at konsumet økte ganske betydelig fra 1993 til 2000, dvs. fra 4,55 liter per innbygger i 1993 til 5,60 liter i 2000 , altså en økning i det registrerte konsumet på $23 \%$. I ungdomsbefolkningen har økningen vært enda større. SIFAs ungdomsundersøkelser viser at selvrapportert alkoholkonsum for 15-20-åringer økte fra 2,92 liter per person per år i 1993 til 5,18 liter i 2001, dvs. en økning på $77 \%$.

Tabell 1. Fordeling av totalkonsumet av alkohol (i liter ren alkohol per innbygger over 15 år) etter drikkesort og omsetningsform. Tallene er hentet fra Horverak et al., 2001. Tallene for registrert salg er fra år 2000, mens estimatene for turistimport, hjemmeprodusert og smuglet alkohol er basert på data fra en survey i den voksne befolkningen i 1999.

\begin{tabular}{lccccc}
\hline & $\begin{array}{c}\text { Registrert } \\
\text { salg }\end{array}$ & $\begin{array}{c}\text { Estimert } \\
\text { turist- } \\
\text { import }\end{array}$ & $\begin{array}{c}\text { Estimert } \\
\text { hjemme- } \\
\text { produsert }\end{array}$ & $\begin{array}{c}\text { Estimert } \\
\text { smuglet }\end{array}$ & Sum \\
\hline$Ø 1$ & 2,86 & 0,04 & $0,04^{* *}$ & & 2,94 \\
Vin & 1,62 & 0,20 & 0,48 & & 2,30 \\
Brennevin & 1,05 & 0,43 & 0,48 & 0,18 & 2,14 \\
Sum & $5,60^{*}$ & 0,67 & 1,00 & 0,18 & 7,38 \\
\hline
\end{tabular}

* Differansen mellom det totale registrerte alkoholsalget $(5,60$ liter) og summen av registrert salg av øl, vin og brennevin $=0,07$ liter, som svarer til det registrerte salget alkoholholdige fruktdrikker.

** Det ble ikke spurt om dette i den siste surveyen i 1999. Estimatet settes til 0,04 på grunnlag av estimater fra tidligere surveyer.

\section{Sammenheng mellom totalkonsum og misbruk}

Kunnskap om totalkonsumet av alkohol i en befolkning er viktig fordi det gir en god indikasjon på omfanget av alkoholmisbruk i befolkningen. Det er riktignok vanskelig å gi et tall for hvor grensen mellom bruk og misbruk går. Eksempelvis viste Duckerts studier (1993) at blant personer som hadde søkt behandling for sine alkoholproblemer, var årskonsumet av alkohol sterkt varierende, og at drikkemønsteret for de langt fleste var preget av vekselvise perioder med høyt, middels eller intet konsum. Men, uansett om vi setter grensen for misbruk/alkoholproblemer/høykonsum ved 30 eller 60 liter ren alkohol i året, er omfanget av misbrukere eller stordrikkere nært knyttet til det totale alkoholkonsumet i befolkningen ${ }^{3}$. Dette henger sammen med at alkoholkonsumet i en befolkning er svært skjevfordelt, og størstedelen av alkoholen drikkes av 


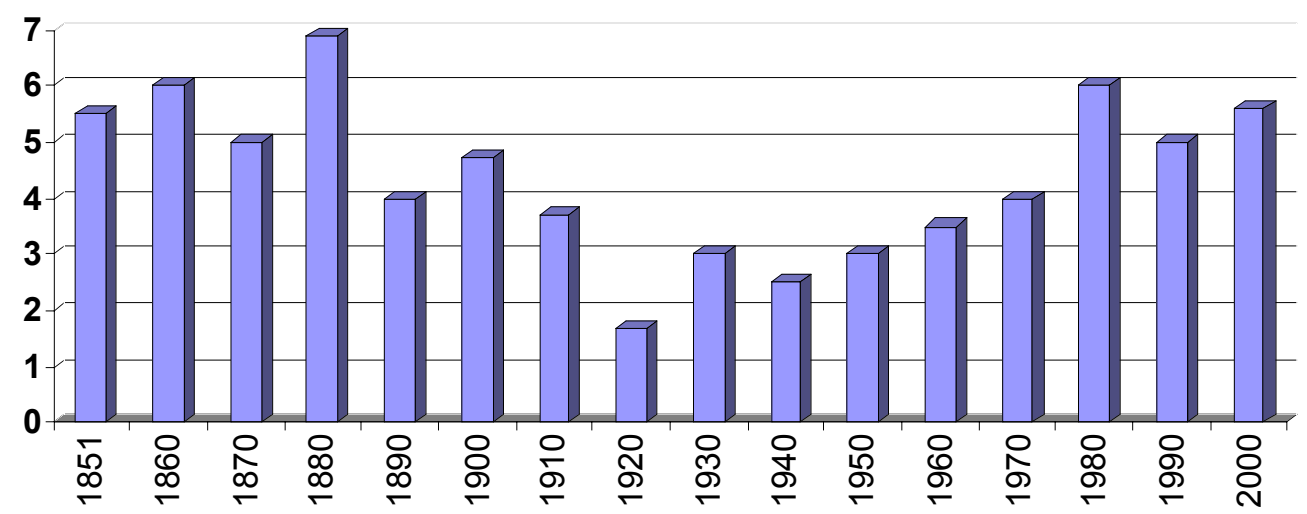

Figur 1. Registrert alkoholkonsum i liter ren alkohol per innbygger over 15 år for enkelte år (med 10 års intervaller) for perioden 1851-2000. Tall fra SIFAs/SIRUS' ungdomsundersøkelser.

en liten del av befolkningen. Skog (1990) beregnet at den tidelen av befolkningen som drikker mest, drikker halvparten av all alkohol her i landet. Greenfield \& Rogers (1999) fant $i$ en studie fra USA at de $20 \%$ av konsumentene som drakk mest, drakk $90 \%$ av det totale forbruket. Ved å sammenlikne totalkonsumet mellom ulike land eller delstater og ved å følge trender i totalkonsumet over tid i et land, kan man derved også få et bilde av forskjeller og endringer i omfanget av alkoholmisbruk $^{4}$. Skog (1985) har vist at når totalkonsumet $\mathrm{i}$ en befolkning øker, øker også konsumet $\mathrm{i}$ alle grupper av konsumenter. Sammenliknet med andre europeiske land, har vi et relativt lavt alkoholkonsum $\mathrm{i}$ Norge, men med økende konsum de siste ti-årene her til lands og en betydelig nedgang i konsumet i søreuropeiske land, er forskjellen i omfanget av stordrikkere og misbruk blitt mindre.

\section{Fordeling av alkoholkonsumet etter demografiske grupper}

Spørreundersøkelser i befolkningen danner grunnlag for å beskrive hvordan alkoholkonsumet varierer med ulike demografiske kjennetegn. Det tidligere Statens institutt for alkohol- og narkotikaforskning (SIFA)s spørreundersøkelser fra 1956 og framover viser at hvor mye vi drikker, varierer systematisk med kjønn, alder, bosted, inntekt og utdanning. Tabell 2 gir en indikasjon på dette. Som vi ser her, drikker menn vesentlig mer enn kvinner, og konsumet er høyest i de yngste aldersgruppene og avtar med økende alder. Byboere drikker mer enn de som bor på mindre steder, og enslige drikker mer enn de som er gift eller samboere (det siste skyldes ikke bare at enslige gjennomsnittlig er noe yngre enn gifte/samboere, også innenfor samme aldersgruppe finner vi at enslige drikker mer enn gifte og samboende). Alkohol er en dyr vare, og vi ser også at konsumet er høyest i gruppen med høyest inntekt.

Til tross for 18-års aldersgrense for kjøp av øl og vin og 20-års grense for kjøp av brennevin, er alkoholkonsumet høyt blant ungdom. Tall fra SIFAs ungdomsundersøkelser (Skretting, 2000) viser at gjennom- snittlig debutalder for alkohol er rundt 14,5 år. Blant 15-16-åringer har 70\% erfaring med alkohol, og blant 17-18-åringer er denne andelen 86\% (Skretting, 2000).

\section{Drikkemonstre}

Tabell 2 viser videre at det er noen systematiske forskjeller med hensyn på hvordan konsumet fordeles mellom ulike drikkesorter. De mest utpregete forskjellene er at vin utgjør en vesentlig større andel av konsumet for kvinner enn for menn, og at øl utgjør en større andel av konsumet for yngre enn for eldre.

Når det gjelder skadepotensiale, er vi særlig opptatt av drikkemønstre som er kjennetegnet ved relativt hyppig beruselse. Det er etter hvert godt dokumentert $\mathrm{i}$ litteraturen at for en rekke alkoholrelaterte skader er et drikkemønster preget av fyll vel så viktig som hvor mye man drikker i løpet av et år (Norström, 2001).

I SIFAs spørreundersøkelse i den voksne befolkningen i 1999 ble det også spurt om antall ganger siste 12 måneder respondenten hadde drukket så mye at han/hun hadde kjent seg tydelig beruset. Som vi ser av Tabell 2, varierer også dette betydelig mellom ulike grupper. Den største forskjellen ser vi med hensyn til alder, - det å drikke seg beruset er klart mest utbredt blant ungdom og unge voksne. Vi ser også at enslige rapporterer oftere om beruselse enn gifte og samboende, og menn drikker seg oftere beruset enn hva kvinner gjør. Det er også en klar korrelasjon mellom totalkonsum og hvor ofte man drikker seg beruset (se f.eks. Rossow, 1996), men denne sammenhengen varierer mellom demografiske grupper. Til tross for at totalkonsumet er økende med økende inntekt, ser vi at det er liten forskjell i beruselsesomfang mellom inntektsgruppene, og det er større variasjon i beruselse enn i totalkonsum mellom aldersgruppene. Dette innebærer at ungdom og unge voksne rapporterer flere episoder av beruselse for hver liter alkohol de drikker sammenliknet med middelaldrende og eldre, mens folk i høyinntektsgrupper rapporterer færre beruselsesepisoder $i$ forhold til alkoholmengde enn folk i lavere inntektsgrupper. 
Drikkemønsteret i Norge likner på det vi ser i Sverige og Finland, - de fleste drikker relativt sjelden, men når de først drikker, så gjør de det til gagns. En stor europeisk undersøkelse av alkoholkonsum, drikkemønstre og alkoholrelaterte skader (Norström, 2001) viste også at vi i disse nordiske landene (Finland, Norge og Sverige) får flere alkoholrelaterte skader for hver liter vi drikker enn hva man gjør i sør-europeiske land.

\section{NARKOTIKA}

\section{Eksperimentering og tungt misbruk}

De viktigste kildene for kunnskap om narkotikabruk i Norge er spørreundersøkelser i befolkningen (ungdomsbefolkningen og den voksne befolkningen) og undersøkelser blant misbrukere i behandling, omsorgstiltak eller arrest/fengsel. Ved å spørre (mer eller mindre) store utvalg av den norske befolkningen om narkotikabruk, fanger vi i hovedsak opp personer som har hatt begrenset erfaring med narkotika (eksperimentell bruk) og i liten eller ingen grad personer med mer omfattende erfaring eller et tungt misbruk. SIFA har foretatt årlige ungdomsundersøkelser om alkohol- og narkotikabruk; i Oslo siden 1968 og i hele landet siden 1990. Ungdomsundersøkelsen blant 15-20-åringer i 2001 viste at hasj/marihuana er det mest utbredte narkotiske stoffet blant ungdom. Tabell 3 viser at andelen som har prøvd hasj er vesentlig større enn andelen som har prøvd noe annet rusmiddel, at andelen med hasjerfaring er noe større blant gutter enn blant jenter, og økende gjennom tenårene. Ungdomsundersøkelsene er postsendte enqueter med en svarprosent rundt 50, og tallene er derfor usikre med hensyn til det absolutte omfanget som har erfaring med narkotiske stoffer, men de tegner trolig et rimelig godt bilde av demografiske variasjoner og trender over tid.

Tabell 2. Gjennomsnittlig alkoholkonsum i liter ren alkohol per år etter demografiske grupper. Selvrapporterte data (basert på SIFAs alkoholundersøkelse i den voksne befolkningen, 1999).

\begin{tabular}{lccccc}
\hline & $\begin{array}{c}\text { Totalt alkohol- } \\
\text { konsum per år }\end{array}$ & $\begin{array}{c}\text { Ølkonsum } \\
\text { per år }\end{array}$ & $\begin{array}{c}\text { Vinkonsum } \\
\text { per år }\end{array}$ & $\begin{array}{c}\text { Brennevins- } \\
\text { konsum per år }\end{array}$ & $\begin{array}{c}\text { Antall ganger } \\
\text { beruset siste år }\end{array}$ \\
\hline Mann & 4,82 & 2,30 & 0,94 & 1,62 & 5,90 \\
Kvinne & 1,94 & 0,66 & 0,89 & 0,38 & 2,17 \\
$15-24$ år & 5,22 & 2,92 & 0,73 & 1,57 & 10,84 \\
$25-39$ år & 3,72 & 1,75 & 0,90 & 1,09 & 5,38 \\
$40-59$ år & 3,47 & 1,37 & 1,12 & 1,00 & 2,22 \\
60 år + & 1,56 & 0,33 & 0,76 & 0,49 & 0,38 \\
By & 3,84 & 1,76 & 1,17 & 0,94 & 4,87 \\
Tettsted & 2,80 & 1,16 & 0,80 & 0,84 & 2,71 \\
Landdistrikt & 2,92 & 1,18 & 0,56 & 1,17 & 3,43 \\
Gift/samboende & 2,62 & 0,97 & 0,94 & 0,71 & 2,31 \\
Ugift/skilt/enke & 4,50 & 2,23 & 0,87 & 1,43 & 6,61 \\
Inntektsgruppe 1 & 2,77 & 1,33 & 0,75 & 0,71 & 4,77 \\
Inntektsgruppe 2 & 3,15 & 1,34 & 0,77 & 1,08 & 3,62 \\
Inntektsgruppe 3 & 3,28 & 1,45 & 0,97 & 0,85 & 3,94 \\
Inntektsgruppe 4 & 5,18 & 2,09 & 1,50 & 1,59 & 4,15 \\
\hline
\end{tabular}

Merk: Gjennomsnittskonsumet basert på selvrapportering i spørreundersøkelser ligger vanligvis på 40-50\% av det tallet for gjennomsnittskonsum som framkommer ved å summere registerert konsum og estimert uregisterert konsum per voksen innbygger, og skyldes flere typer feilkilder ved bruk av survey-metoder.

Tabell 3. Andel av 15-20-åringer som rapporterer å noen gang ha brukt ulike rusmidler. Prosent. Kilde: Skretting (2000), Ungdom og rusmidler, Statens institutt for rusmiddelforskning, og Statens institutt for rusmiddelforskning, SIRUS (2001).

\begin{tabular}{lrccccccc}
\hline & Hasj & 'Sniffet' & $\begin{array}{c}\text { Amfe- } \\
\text { tamin }\end{array}$ & $\begin{array}{c}\text { Kokain } \\
\text { crack }\end{array}$ & LSD & Ecstasy & GHB & $\begin{array}{c}\text { Heroin } \\
\text { opiater }\end{array}$ \\
\hline Alle* & 16,9 & 5,4 & 4,6 & 1,6 & 1,1 & 3,0 & 1,1 & 0,8 \\
Gutter & 17,5 & 7,0 & & & & & & \\
Jenter & 15,0 & 5,5 & & & & & & \\
$15-16$ & 9,0 & 6,0 & & & & & & \\
$17-18$ & 20,0 & 6,7 & & & & & & \\
$19-20$ & 25,0 & 5,7 & & & & & & \\
Oslo & 26,0 & 6,2 & & & & & & \\
\hline
\end{tabular}

* Tallene for "Alle" er hentet fra den siste ungdomsundersøkelsen i 2001, mens tallene for fordelinger på andel som har brukt hasj eller har sniffet, er basert på 3-årig gjennomsnitt (1997-1999) (Skretting, 2000). 
Et stort europeisk komparativt prosjekt om ungdoms bruk av rusmidler (ESPAD) gir grunnlag for å sammenlikne rusmiddelbruk blant 15-16-åringer i et tyvetalls europeiske land (Hibell et al., 2000). ESPADundersøkelsen fra 1999 viste at andelen tenåringer i Norge som hadde prøvd hasj, var lavere enn i Danmark, Irland, Italia, England og Frankrike, omtrent på samme nivå som Finland, Island, Polen og Ungarn, men noe høyere enn i Sverige, Portugal og på Færøyene.

"Hvor mange narkomane har vi i Norge?" er et spørsmål som hyppig stilles, og som nødvendigvis må besvares med visse forbehold. To nyere studier (Hauge \& Østby, 1998; Bretteville-Jensen \& Ødegård, 1999) har ved bruk av svært ulike metoder kommet fram til omtrentlig samme estimat, dvs. omkring 9000-12000 tunge narkotikamisbrukere ${ }^{5}$ i Norge. De fleste av disse er hovedsakelig heroinbrukere, mens en liten andel primært injiserer amfetamin. Det tunge narkotikamisbruket i Norge skiller seg trolig fra det man ser i en rekke andre europeiske land, ved at inntaksmåten $i$ hovedsak er injisering (Arner et al., 1995), og at det er bruk av heroin og til dels amfetamin som dominerer bildet (til fortrengsel for kokain/crack).

Sammenlikner vi demografiske trekk ved eksperimentell rusmiddelbruk og tungt misbruk, finner vi både parallelle og divergerende mønstre. Både eksperimentell bruk og tungt misbruk finner vi i større grad i storbyer enn på mindre steder. På den annen side er kjønnsforskjellene relativt små når vi ser på eksperimentell bruk av narkotika, men blant de tyngre misbrukerne finner vi en vesentlig større andel menn; - i behandlingstiltak er forholdet menn: kvinner omtrent $2: 1$, i fengsler og varetekt omtrent $5: 1$, og ved overdosedødsfall omtrent $4: 1$.

\section{Utvikling av narkotikabruk i Norge}

Andelen av ungdom som rapporterer at de noen gang har brukt ulike narkotiske stoffer for årene 1990-2001 er gjengitt i Figur 2. Det er verdt å merke seg den betydelige økningen på slutten av 90 -tallet $\mathrm{i}$ andelen av ungdommer som har brukt hasj og også andre stoffer. Tilsvarende trend sees også for andelen av ungdom som har brukt hasj siste 6 måneder. Økningen har skjedd parallelt med økningen i alkoholkonsum i ungdomsbefolkningen. Tall fra ESPAD-undersøkelsene i 1995 og 1999 viser en tilsvarende trend i mange andre europeiske land, dvs. en økning i andelen av 15-16åringer som har brukt hasj eller andre narkotiske stoffer noen gang (Hibell et al., 2000).

Også når det gjelder det tunge misbruket, har vi indikasjoner på at dette har økt gjennom 1990-tallet. Skog (1990) beregnet at det ved slutten av 1980-tallet var omkring 4000-5000 injiserende misbrukere i Norge. Med tilsvarende beregningsmåter fant altså Bretteville-Jensen \& Ødegård i 1999 et dobbelt så høyt antall injiserende misbrukere. Både trender for ungdoms erfaring med narkotika og indikasjoner på tungt misbruk viser et økende omfang gjennom 1990-tallet, men også at økningen har vært større i andre deler av landet enn i Oslo (Bretteville-Jensen \& Ødegård, 1999), slik at den tradisjonelle by-land-forskjellen er blitt mindre (Skretting, 2001).

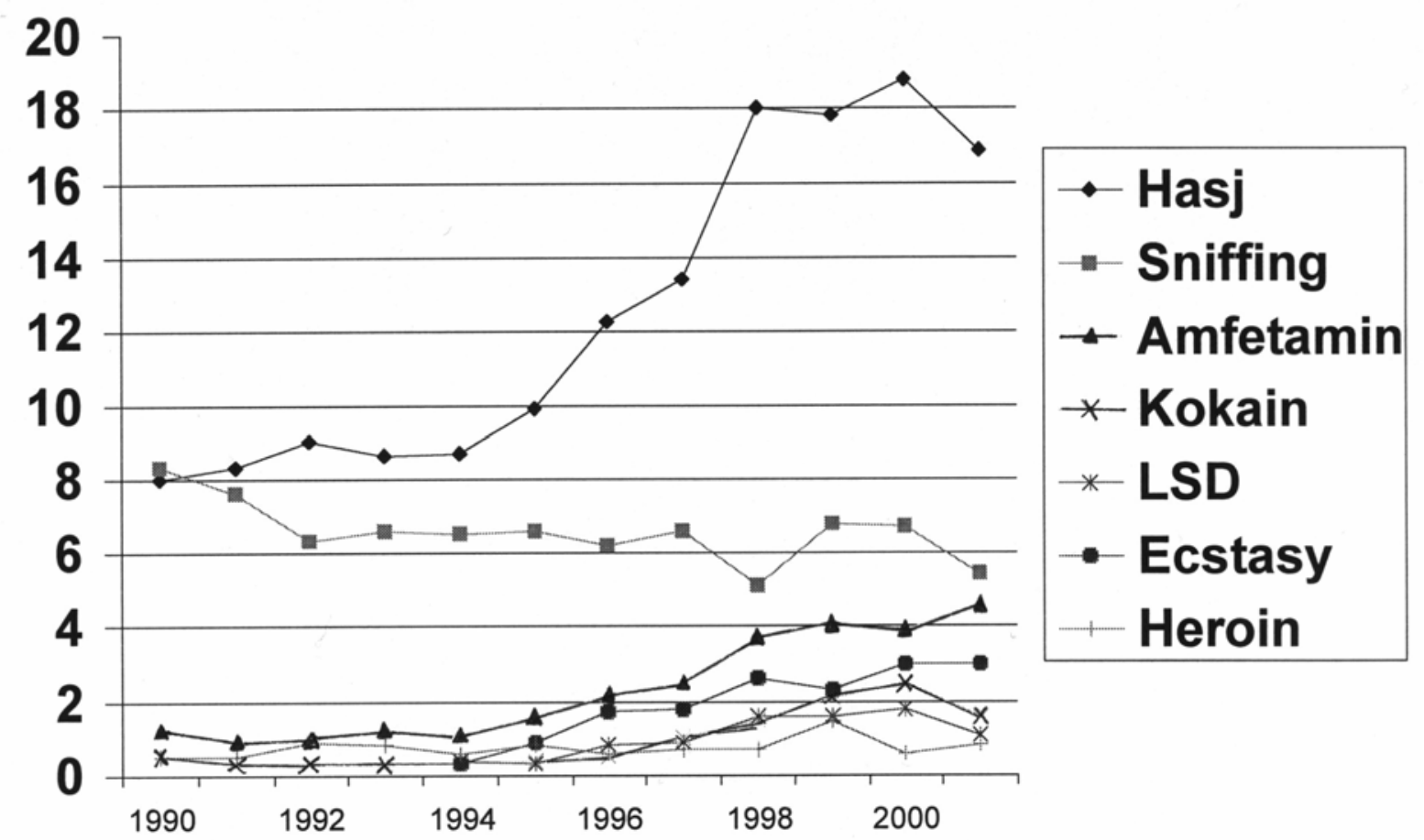

Figur 2. Andel av 15-20-åringer i Norge som rapporterer at de noen gang har brukt ulike rusmidler for årene 19902001. prosent. 


\section{Karrieremonstre}

Hva kjennetegner utviklingen fra eksperimentell utprøving til tungt misbruk? Det finnes få studier som har fulgt tilstrekkelig store befolkningsgrupper over tilstrekkelig lang tid og med tilstrekkelig god oppfølging til å beskrive dette godt. Likevel kan vi på grunnlag av noen gode kohortstudier samt retrospektive data fra klienter i behandling tegne et bilde av noen kjennetegn og risikofaktorer. Pedersen (1998) fant i en 7-års oppfølgingsstudie av ungdom at utvikling av et illegalt rusmiddelbruk fulgte et mønster, hvor alkoholbruk var det første 'steget', fulgt av sigaretter, og deretter hasj før evt. bruk av andre narkotiske stoff. Også tverrsnittsstudier viser en klar sammen heng mellom hasjbruk og erfaring med andre stoff. Det finnes knapt noen som oppgir å ha brukt amfetamin, ecstasy eller heroin, som ikke også har prøvd hasj. Andelen som har prøvd andre stoffer øker også med økende hasjerfaring. Skretting (2000) har vist at det er en klar sammenheng mellom bruk av ulike narkotiske stoff, - dvs. har du prøvd ett stoff (f.eks. hasj), er det også mer sannsynlig at du har prøvd andre stoffer. Dette gjelder både livstidserfaring og bruk siste 6 måneder.

Studier av stoffmisbrukere i behandling viser også at disse har begynt tidlig med alkohol og tobakk, og de fleste røykte hasj regelmessig før de var ferdige med ungdomsskolen (Arner et al., 1995). Flertallet av stoffmisbrukere har en omfattende erfaring med en rekke ulike rusmidler, og blandingsmisbruk er det dominerende bildet i denne gruppen (Arner et al., 1995; Lauritzen et al., 2001). Det vil si at "den rene heroinbruker" knapt finnes. Injiserende bruk av heroin og/eller amfetamin er vanligvis kombinert med bruk av flere andre rusmidler, - oftest hasj, alkohol og beroligende midler.

\section{Nye stoffer - nye trender?}

På 1990-tallet kom ecstasy til Norge, parallelt med oppveksten av en ny ungdomskultur hvor musikk, uteliv, klær og partydop var en del av en 'stil-pakke' (Moshuus et al., 2002). Hallucinogene stoffer som LSD så ut til å få en 'renessanse', og bruk av ecstasy, amfetamin og kokain økte også i ungdomsbefolkningen på slutten av 1990-tallet (Figur 2). Studier fra andre europeiske land og en studie fra Oslo (Sand, 2000) pekte i retning av at vi nå sto overfor et nytt fenomen; at bruk av nye stoffer i nye kulturelle kontekster var forbundet med nye bruksmønstre, hvor brukerne var ressurssterk, veltilpasset ungdom, og at bruken av nye stoffer kom til erstatning for alkohol og hasj. Nyere populasjonsstudier av ungdom bekrefter ikke dette bildet, snarere tvert i mot. Blant ungdom som oppgir å ha brukt partydop som amfetamin, ecstasy, LSD, eller kokain, er alkoholkonsumet høyere, og de aller fleste har også brukt hasj i samme periode (f.eks. Pedersen \& Bakken, 1998; Pedersen \& Skrondal, 1999; Skretting, 2000). Dette betyr at blant vanlig ungdom, hvor vi fanger opp den tidlige eksperimen- telle bruken, er ecstasy en del av et mer omfattende rusmiddelbruk, hvor høyt alkoholkonsum og hasjbruk også utgjør en del av bildet.

Men også i andre ungdomsgrupper med et mer omfattende rusmiddelbruk, gjerne knyttet til house- og raveparties, finner vi tilsvarende blandingsbruk. Nye tall fra Uropatruljens undersøkelse blant arrestanter fra raveparties o.l. i Oslo, viser at omlag tre fjerdedeler av disse ungdommene bruker hasj, og en tilsvarende andel bruker ecstasy, mens litt over halvparten bruker amfetamin. Bruk av kokain, GHB, LSD og piller var mindre vanlig (Hoff-Olsen, personlig kommunikasjon, 2001).

\section{Avhengighetsskapende legemidler}

Misbruk av beroligende og sterke smertestillende legemidler er et felt hvor vi har lite kunnskap, dette til tross for at omfanget antakelig er ganske stort. Statistikk over omsetningen av benzodiazepiner og benzodiazepinderivater gir et bilde av trender $\mathrm{i}$ den totale omsetningen og hvordan dette varierer mellom fylker (SIRUS, 2001). For begge disse gruppene var det en nedgang i omsetningen fra slutten av 1980-tallet og fram til midten av 1990-tallet, og deretter en viss økning igjen. I år 2000 ble det omsatt 18,0 DDD (definerte døgndoser) per innbygger av benzodiazepiner, og 31,8 DDD av hypnotika og sedativa. De tilsvarende tallene for 1988 var henholdsvis 24,4 DDD og 45,0 DDD.

Survey-studier indikerer at bruk av avhengighetsskapende legemidler er svært skjevfordelt i befolkningen, men det er usikkert om endringer $\mathrm{i}$ den totale omsetningen speiler endringer i omfanget av misbruk, slik det gjør for alkoholkonsumet. En apotekstudie av omsetning av B-preparater (smertestillende, hypnotika, beroligende og hostemikstur) på Sørvestlandet viste at en fjerdedel av kundene sto for over halvparten av omsetningen av B-preparatene (målt i definerte døgndoser) (Smith-Solbakken et al., 1996). Surveydata fra SIFAs rusmiddelundersøkelse i den voksne befolkningen 1994 viser at hyppig bruk (daglig/nesten daglig siste år) av avhengighetsskapende legemidler varierer svært systematisk med kjønn, alder og helsesituasjon (Figur 3). Vi ser at kvinner, eldre og syke og ensomme langt oftere er hyppige brukere av slike legemidler enn andre, og variasjonsmønsteret blir derved i stor grad omvendt av det vi ser for alkoholbruk. Apotekstudien fra Sørvestlandet viste også at eldre kunder (over 70 år) utgjør $26 \%$ av alle kundene og står for $40 \%$ av den totale omsetningen av B-preparater. Legemiddelmisbruk ser ofte ut til å være kombinert med alkoholmisbruk eller narkotikamisbruk (Krogh, 1988; Arner et al., 1995).

\section{Kort oppsummering og implikasjoner for videre forskning}

Alkohol er det desidert mest utbredte rusmiddelet $\mathrm{i}$ befolkningen, og det er også med all sannsynlighet det 


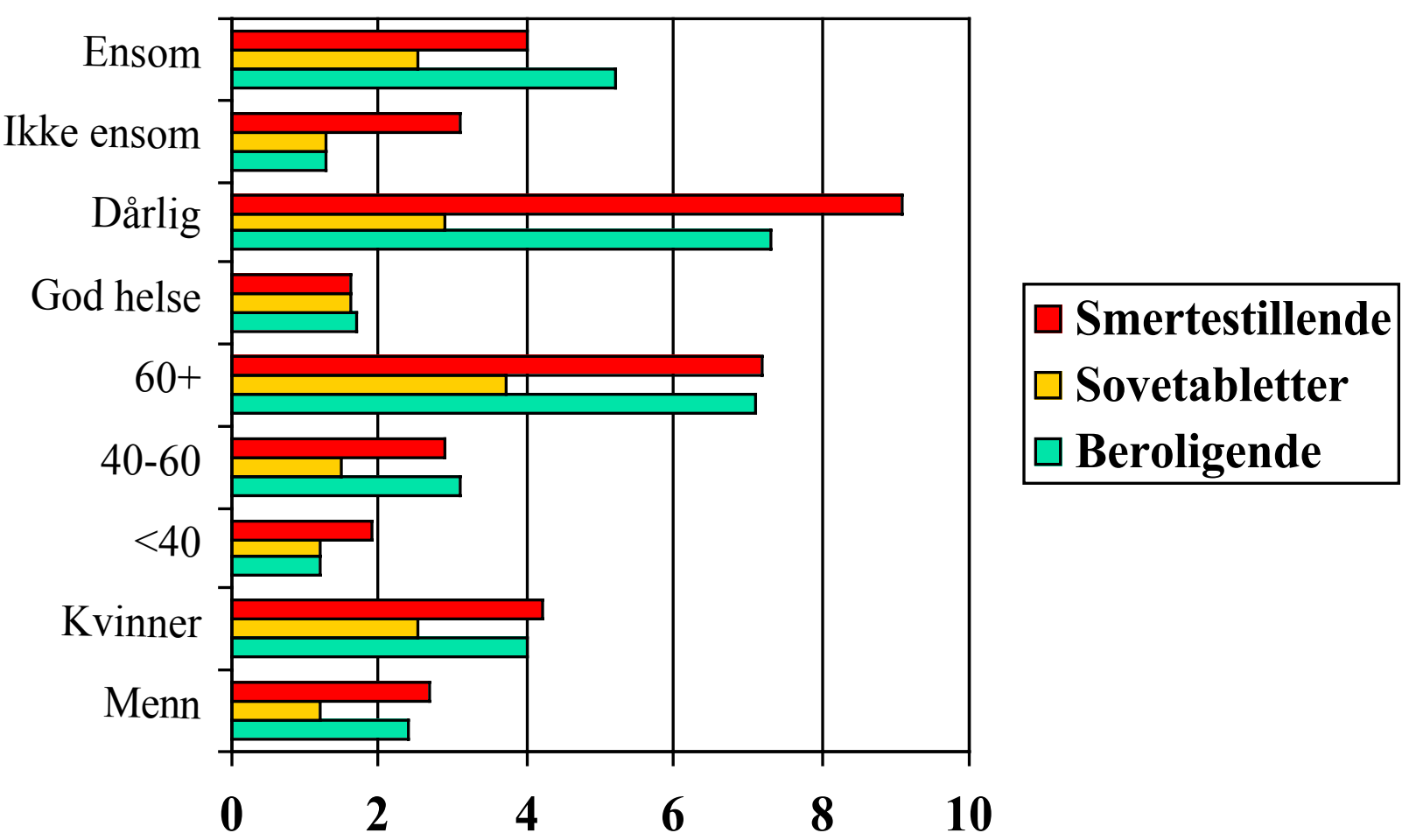

Figur 3. Andel som oppgir daglig eller nesten daglig bruk av hhv. sterke smertestillende tabletter, sovetabletter og beroligende midler, etter kjønn, aldersgruppe, subjektivt opplevd helse og ensomhetsfølelse. Prosent. Tidligere upubliserte data fra SIFAs alkoholundersøkelse i 1994.

rusmiddelet som medfører det største misbruksproblemet. Alkoholkonsumet er høyest blant unge voksne, og det er også i denne gruppen at omfanget av fyll er størst, og dermed også potensialet for en rekke alkoholrelaterte skader. Det er derfor særlig bekymringsfullt at alkoholkonsumet har økt betydelig blant 15-20åringer gjennom slutten av 1990-tallet. Både denne utviklingen og den reduserte oppslutningen om kontrollpolitiske tiltak for å begrense alkoholkonsumet, tilsier at et bedre kunnskapsgrunnlag for å utvikle og implementere gode alternative forebyggingstiltak bør være et viktig satsingsfelt framover.

Både andelen ungdom som har erfaring med narkotika og omfanget av injiserende stoffmisbrukere har økt betydelig i løpet av det siste tiåret. Særlig har om- fanget av hasjbruk blant ungdom økt og er trolig blitt mer 'alminneliggjort'. Hvorvidt illegal rusmiddelbruk, og kanskje i særlig grad hasj, i økende grad er blitt en del av en livsstil blant ressurssterk veltilpasset ungdom vil være ett av flere viktige forskningstema framover. En bedre kunnskap om utvikling av rusmiddelkarrierer vil være et annet viktig tema.

Selv om bruk og misbruk av avhengighetsskapende legemidler trolig har mindre dramatiske helsemessige og sosiale konsekvenser enn alkohol- og narkotikamisbruk, er omfanget antakelig stort og problemet betydelig for dem det gjelder. Dette er et tema som er klart underforsket, og det bør bli en prioritert oppgave innenfor de relevante forskningsmiljøene å styrke forskningen på dette feltet.

\section{Noter}

${ }^{1}$ Jeg bruker her begrepet misbruk temmelig vidt og upresist for en konsumkategori hvor konsumet er svært høyt og/eller problematisk. Dette for å unngå å bruke en rekke ulike termer som 'alkoholiker', 'narkoman', 'høykonsument', 'stordrikker', problemdrikker', 'avhengig', osv.

${ }^{2}$ Omfanget av det uregistrerte konsumet er i hovedsak basert på spørsmål om kjøp/bruk av hjemmebrent og smuglersprit, om egen innførsel av alkohol fra utlandet og om egen vinlegging/ølbrygging. Det hefter derfor rimeligvis betydelig usikkerhet til disse estimatene.

${ }^{3}$ Dersom vi setter grensen for høykonsum eller misbruk til det å drikke mer enn $10 \mathrm{cl}$ ren alkohol per dag (mer enn 36,5 liter ren alkohol i året), har vi om lag 60.000 alkoholmisbrukere. Dersom vi setter grensen til halvparten, dvs. 18 liter ren alkohol i året, har vi om lag 300.000 alkoholmisbrukere. 
${ }^{4}$ Dette har i første rekke gyldighet i de fleste europeiske og nord-amerikanske land. I land hvor størstedelen av befolkningen ikke drikker alkohol, vil det være et betydelig sprik mellom gjennomsnittskonsumet per voksen innbygger og gjennomsnittskonsumet per konsument.

${ }^{5}$ Hauge \& Østby (1998) fant at det var ca. 12.000 sprøytebrukere mens Bretteville-Jensen \& Ødegård (1999) har beregnet 9.000-12.000 injiserende misbrukere.

\section{REFERANSER}

Arner O, Lauritzen G, Waal H, Amundsen A (1995). Forprosjekt til en nasjonal studie av stoffmisbrukere i behandling. SIFA-rapport nr. 3/95 (Oslo, Statens institutt for alkohol- og narkotikaforskning).

Bretteville-Jensen AL, Ødegård E (1999). Injeksjonsmisbrukere i Norge. SIFA-rapport nr. 4/99 (Oslo, Statens institutt for alkohol- og narkotikaforskning).

Duckert F (1993). Alcohol problems and treatment (Oslo, Statens institutt for alkohol- og narkotikaforskning).

Greenfield TK, Rogers JD (1999). Who drinks most of the alcohol in the U.S.? The policy implications. $J$ Stud Alcohol 60: 78-89.

Hauge R, Østby L (1998). Narkotikabruk i kommunene 1993-1996 (Oslo, Rusmiddeldirektoratet og Statens institutt for alkohol- og narkotikaforskning).

Hibell B, Andersson B, Bjarnasson B, Kokkevi A, Morgan M, Narusk A (2000). The 1999 ESPAD report (Stockholm, Swedish Council for Information on Alcohol and Other Drugs).

Horverak Ø, Nordlund S, Rossow I (2001). Om sentrale deler av norsk alkoholpolitikk. SIRUS-rapport nr. 1/01 (Oslo, Statens institutt for rusmiddelforskning).

Krogh P (1988). Pasienter i A-klinikker og kursteder. SIFA-rapport nr. 1/88 (Oslo, Statens institutt for alkohol- og narkotikaforskning).

Lauritzen G, Melberg HO, Ravndal E (2001). Nytte-kostnad Prosjektet. Noen resultater fra andre oppfølgingsundersøkelse. Nyhetsbrev nr. 3 (Oslo, Statens institutt for rusmiddelforskning).

Moshuus G, Rossow I, Vestel G (2002). Partydop og ungdomskultur (Oslo, NOVA).

Norström T (2001). Alcohol in postwar Europe: Consumption, drinking patterns, consequences and policy responses in 15 European countries (Stockholm University, Stockholm).

Pedersen W, Bakken A (1998). Ecstasy. Tidsskr samfunnsforskn 39: 49-77.

Pedersen W, Skrondal A (1999). Ecstasy and new patterns of drug use: a normal population study. Addiction 94: 1695-1706.

Rossow I (1996). Alcohol related violence; - the impact of drinking pattern and drinking context. Addiction 91: 1641-1651.

Sand A (2000). Dop er greit så lenge det ikke styrer livet ditt. Hovedfagsoppgave i antropologi, Universitetet i Oslo, Oslo.

SIRUS (2001). Rusmidler i Norge (Oslo, Statens institutt for rusmiddelforskning).

Skog O-J (1990). Utviklingen av intravenøst narkotikamisbruk - Anslag for insidens og prevalens. SIFA-rapport nr. 1/90 (Oslo, Statens institutt for alkohol- og narkotikaforskning).

Skog O-J (1985). The collectivity of drinking cultures. A theory of the distribution of alcohol consumption. $\mathrm{Br} J$ Addict 80: 83-99.

Skretting A (2000). Ungdom og rusmidler (Oslo, Rusmiddeldirektoratet).

Skretting A (2001). By og land - hand i hand. Endringer i narkotikabruk blant ungdom. Tidsskrift for Ungdomsforskning 1: 109-115.

Smith-Solbakken M (1996). Legemidler på avveier - sammendragsrapport. RF-rapport 96/252 (Stavanger, Rogalandsforskning). 